\title{
The brain drain: why medical students and young physicians want to leave Egypt
}

Ibrahim Kabbash, ${ }_{1}$ Rania El-Sallamy, ${ }^{2}$ Hanaa Zayed, ${ }^{2}$ Ibrahim Alkhyate, ${ }^{3}$ Ahmed Omar ${ }^{3}$ and Sanaa Abdo ${ }^{1}$

${ }^{1}$ Department of Public Health and Community Medicine, Faculty of Medicine, Tanta University, Tanta, Egypt. ${ }^{2}$ Occupational Medicine, Department of Public Health and Community Medicine, Faculty of Medicine, Tanta University, Tanta, Egypt. ${ }^{3}$ Faculty of Medicine, Tanta University, Tanta, Egypt (Correspondence to: Ibrahim A. Kabbash: Ibrahim.kabbash@med.tanta.edu.eg, iafkabbash@gmail.com).

\begin{abstract}
Background: Egypt has a shortage of physicians despite thousands of medical students graduating annually.

Aims: This study aimed to explore the reasons for Egyptian medical students and young physicians wanting to emigrate. Methods: This cross-sectional study, conducted from February to April 2019, included 711 fifth- and sixth-year medical students and 174 residents from two medical faculties in Egypt, Tanta and Kafrelshiekh. A questionnaire was used to collect data on sociodemographic factors, desire to emigrate and motives for wanting to emigrate.

Results: Most participant (89.4\%) wanted to emigrate, and thought their salary was not compatible with their working hours or risks. About half the participants (52.8\%) worked part-time in private hospitals. Only $4.9 \%$ of participants felt appreciated by the country. Most participants (75.9\%) were not satisfied with their relationship with patients and $40.2 \%$ were not satisfied with their relationship with colleagues. Verbal abuse was reported by $55.5 \%$ of participants and physical assaults by $35.4 \%$. Most participants who wanted to emigrate $(85.1 \%)$ said they would change their minds if improvements were made in the health sector. Residents generally had less negative attitudes to workplace and professional factors than students.

Conclusion: Physicians emigrate to seek better work and financial incentives. A retention policy needs to be developed to prevent Egyptian physicians from emigrating.

Keywords: emigration, physicians, workplace, motivation, Egypt

Citation: Kabbash I; El-Sallamy R; Zayed H; Alkhyate I; Omar A; Abdo S. The brain drain: why medical students and young physicians want to leave Egypt. East Mediterr Health J. 2021;27(11):1102-1108. https://doi.org/10.26719/emhj.21.050

Received: 18/01/21; accepted: 04/04/21

Copyright (C) World Health Organization (WHO) 2021. Some rights reserved. This work is available under the CC BY-NC-SA 3.0 IGO license https:// creativecommons.org/licenses/by-nc-sa/3.o/igo
\end{abstract}

\section{Introduction}

Universal health coverage is a priority goal for the World Health Organization (WHO) that needs an adequate, skilled and motivated health workforce to be achieved (1). Migration of physicians from low- and middle-income countries (LMICs) to high-income countries (HICs), the so-called brain drain, is an area of concern that threatens the sustainability of health systems in LMICs (2). Health workers are under pressure for a number of reasons: high cost of training, attrition, migration and increasing demands of ageing populations (3).

In 2013, WHO estimated a global shortage of 7.2 million health care providers (1). This shortage is predicted to reach 15 million by 2030 (4). This shortage is worsened in LMICs by migration of educated health workers to HICs (5-7). The brain drain is especially affecting Africa, which has $25 \%$ of the global disease burden and only $3 \%$ of the health workforce (8). Losses in health workforce in some African countries may reach up to $70 \%$ due to migration, with one fifth of African-born physicians estimated to be working in HICs (9). Losses of trained health personnel from already stressed health systems leave the remaining professionals overwhelmed and demoralized. This exacerbates the problem of low doctor-to-population ratios in many developing countries, leading to a critical lack of services and a reduction in the quality of care provided (10-12).

Egypt suffers from a shortage of physicians despite thousands of medical students graduating annually. In 2016, the density of physicians was estimated to be 1 physician per 12285 inhabitants (13). Emigration of physicians intensifies physician shortages in Egypt and the loss cannot be replaced by recruitment (14). Despite being a major supplier of immigrant medical graduates, little is known about the pattern of physician migration and its associated factors. Therefore, we explored factors associated with migration among medical students, who are the future physicians, and junior resident physicians in two university hospitals in Egypt.

\section{Methods}

\section{Study design, setting and participants}

We carried out a cross-sectional study in the Nile Delta region university hospitals during the period from February to April 2019. The Nile Delta Region has eight faculties of medicine, from which two medical faculties were chosen randomly, Tanta and Kafrelshiekh. The target population of this study were undergraduate medical students in the final clinical grades (5th and 6th years) 
and junior staff physicians (residents) in university hospitals. The total number of students enrolled in these two faculties was 2327 and the total number of resident physicians was 510. Departments from academic years were selected randomly and students in these departments were included in the study. All residents in surgery and internal medicine departments were selected for the study. We aimed to include about $30 \%$ of the total target population in our study. Thus 711 students and 174 residents were selected.

\section{Data collection}

Data were collected using an electronic questionnaire to determine sociodemographic data, students' and physicians' desire to emigrate and different motives for emigration. The questionnaire was posted on the links used by students of each academic year and junior physicians of university hospitals, and we continued to accept responses until we achieved the desired sample size. The questionnaire included a message to participants explaining the objectives of the study and asking them to complete the form if they wished to participate.

\section{Data analysis}

Data were coded and sorted, and analysis were done using SPSS, version 23. Data are presented as number and percentages. The chi-squared test was used to assess significant differences between the students and residents. When the chi-squared was not appropriate for analysis of the observed data, we used the Fisher exact test. $P<0.05$ was considered statistically significant.

\section{Ethical considerations}

The study was approved by the Internal Review Board of Tanta Faculty of Medicine (no. 33478/11/18). Students were considered to have consented to participate if they completed the questionnaire after reading the explanation of the objectives of the study. Confidentiality was guaranteed and data were collected anonymously.

\section{Results}

Our study included 885 participants aged 20 to 25 years. Most of the participants had considered emigration as an option (89.4\%), with no statistically significant difference between students and residents; $89.6 \%$ and $88.5 \%$, respectively (Table 1). Among residents who wished to emigrate, 97.4\% would consider changing their decision if the health sector improved, which was significantly higher than the students $(82.1 \%)$. Only $1.0 \%$ of participants were satisfied with current salary for physicians, $6.0 \%$ and $6.1 \%$ perceived the salary as appropriate given the work risks and work hours, respectively, with statically significant differences between students and residents $(P=0.001)$. More than half of the participants $(52.8 \%)$ expected to have to work part-time in private hospitals because of inadequate salaries with a statically significant difference between students and residents $(P=0.002)$ (Table 1)

\begin{tabular}{|c|c|c|c|c|c|}
\hline \multirow[t]{2}{*}{ Variable } & $\begin{array}{l}\text { Students } \\
(n=711)\end{array}$ & $\begin{array}{l}\text { Residents } \\
(n=174)\end{array}$ & $\begin{array}{c}\text { Total } \\
(n=885)\end{array}$ & \multirow[t]{2}{*}{$\chi^{2}$} & \multirow[t]{2}{*}{$\mathbf{P}$} \\
\hline & No. (\%) & No. $\%$ & No. $\%$ & & \\
\hline Wish to emigrate & $637(89.6)$ & $154(88.5)$ & $791(89.4)$ & 0.17 & 0.677 \\
\hline Change decision if health sector improved $(n=791)$ & $523(82.1)$ & $150(97.4)$ & $673(85.1)$ & 21.68 & 0.001 \\
\hline \multicolumn{6}{|l|}{ Financial factors } \\
\hline Satisfied with physicians' salary & $3(0.4)$ & $6(3.4)$ & $9(1.0)$ & $\mathrm{FE}$ & 0.003 \\
\hline Salary is appropriate for work risks & $32(4.5)$ & $21(12.1)$ & $53(6.0)$ & 14.22 & 0.001 \\
\hline Salary is appropriate for work hours & $34(4.8)$ & $20(11.5)$ & $54(6.1)$ & 10.99 & 0.001 \\
\hline $\begin{array}{l}\text { Need to work extra time in private hospital because salary is } \\
\text { inadequate }\end{array}$ & $357(50.2)$ & $110(63.2)$ & $467(52.8)$ & 9.49 & 0.002 \\
\hline Want to emigrate because salary is inadequate & $470(66.1)$ & $148(85.1)$ & $618(69.8)$ & 23.84 & 0.001 \\
\hline \multicolumn{6}{|l|}{ Work load } \\
\hline Reasonable work hours per week & $165(23.2)$ & $72(41.4)$ & $237(26.9)$ & 23.55 & 0.001 \\
\hline Work hours leave enough time for family & $150(21.1)$ & $74(42.5)$ & $224(25.3)$ & 33.97 & 0.001 \\
\hline Work hours leave enough time for hobbies and activities & $116(16.3)$ & $52(29.9)$ & $168(19.0)$ & 16.74 & 0.001 \\
\hline Have to work extra hours to cover for absent colleagues & NA & $128(73.6)$ & NA & NA & NA \\
\hline \multicolumn{6}{|l|}{ Sociopolitical factors } \\
\hline Enough appreciation from society & $265(37.3)$ & $76(43.7)$ & $341(38.5)$ & 2.42 & 0.120 \\
\hline Enough appreciation from the government & $29(4.1)$ & $14(8.0)$ & $43(4.9)$ & 4.76 & 0.029 \\
\hline Media negatively affect physicians regarding medical errors & $663(93.2)$ & $168(96.6)$ & $831(93.9)$ & 2.66 & 0.103 \\
\hline Need to improve social position & $640(90.0)$ & $158(90.8)$ & $798(90.2)$ & 0.10 & 0.754 \\
\hline
\end{tabular}


Only $38.5 \%$ of participants thought that physicians received enough appreciation form society. Few (4.9\%) considered that country appreciated physicians enough, which was significantly higher among residents compared with students $(8.0 \%$ and $4.1 \%$, respectively; $P=0.029)$. Most of the participants $(93.9 \%)$ agreed about the negative attitude of the media towards physicians. A large majority of both students and residents thought there was a need to improve the social position of physicians (Table 1).

Most of the participants $(75.9 \%)$ were not satisfied with their relationship with patients. Only $12.4 \%$ were totally satisfied with relations with colleagues and $6.2 \%$ with relations with nursing staff, with significant differences between students and residents $(P=0.001)$. Verbal abuse of physicians during their work was reported by $55.5 \%$ of the participants, while $35.4 \%$ reported physical assault and $25.5 \%$ reported violations of their privacy (e.g. patients trying to access the physician's consulting rooms even when he/she is on a rest period). Significantly more students reported all types of abuse than residents $(P=0.001)$. About half of the participants $(48.8 \%)$ considered that their workplace was safe and most $(87.9 \%)$ thought that administrative procedures negatively affected their work, with no significant differences between the students and residents (Table 2).

About a third of participants $(34.7 \%)$ thought that having a university education made a good doctor with significantly more residents than students believing this
( $P=0.001)$. Only $18.8 \%$ of the participants reported that good opportunities and facilities for scientific research were available and most (87.2\%) wanted to emigrate for better research opportunities, with significantly more residents wanting this than students $(P=0.001)$ (Table 3$)$.

Just over half of the participants (52.1\%) thought that insurance against professional errors was enough and appropriate, with significantly more residents than students agreeing with this $(P=0.001)$. Only $19.3 \%$ of participants considered that enough adequate surgical and medical supplies were available. There was also low satisfaction with the accommodation provided for physicians in hospitals, occupational infection compensation, the medical staff/patients ratio and the job promotion procedures (Table 3 ).

\section{Discussion}

The migration of skilled Egyptian physicians to HICs is the main cause of physician shortages in Egypt (14). Migration is the result of various "push" and "pull" forces operating; for example, the push to seek better working conditions and escape form hard working situations, and the pull the desire to be near family and relatives and to stay in one's homeland. Thus, exploring factors motivating migration among medical students and junior physicians in Egypt can help find solutions to improve the health care system in the country to match physicians' needs and expectations.

Table 2 Work environment factors motivating the desire to emigrate among Egyptian medical students and residents

\begin{tabular}{|c|c|c|c|c|c|}
\hline \multirow[t]{2}{*}{ Variable } & $\begin{array}{l}\text { Students } \\
(n=711)\end{array}$ & $\begin{array}{l}\text { Residents } \\
(n=174)\end{array}$ & $\begin{array}{c}\text { Total } \\
(n=885)\end{array}$ & $\chi^{2}$ & $\mathbf{P}$ \\
\hline & No. (\%) & No. (\%) & No. (\%) & & \\
\hline Relationship with patients & & & & 14.51 & 0.001 \\
\hline Totally satisfied & $17(2.4)$ & $6(3.4)$ & $23(2.6)$ & & \\
\hline Satisfied & $171(24.0)$ & $19(11.0)$ & $190(21.5)$ & & \\
\hline Not satisfied & $523(73.6)$ & $149(85.6)$ & $672(75.9)$ & & \\
\hline Relationship with colleagues & & & & 23.78 & 0.001 \\
\hline Totally satisfied & $74(10.4)$ & $36(20.7)$ & $110(12.4)$ & & \\
\hline Satisfied & $362(50.9)$ & $57(32.8)$ & $419(47.3)$ & & \\
\hline Not satisfied & $275(38.7)$ & $81(46.5)$ & $356(40.3)$ & & \\
\hline Relationship with nursing staff & & & & 16.03 & 0.001 \\
\hline Totally satisfied & $39(5.5)$ & $16(9.2)$ & $55(6.2)$ & & \\
\hline Satisfied & $297(41.8)$ & $45(25.9)$ & $342(38.7)$ & & \\
\hline Not satisfied & $375(52.7)$ & $113(64.9)$ & $488(55.1)$ & & \\
\hline \multicolumn{6}{|l|}{ Experienced abuse in the workplace } \\
\hline Verbal abuse & $354(49.8)$ & $137(78.7)$ & $491(55.5)$ & 47.42 & 0.001 \\
\hline Physical assault & $290(40.8)$ & $23(13.2)$ & $313(35.4)$ & 46.48 & 0.001 \\
\hline Privacy violation & $203(28.6)$ & $23(13.2)$ & $226(25.5)$ & 17.28 & 0.001 \\
\hline Patients neglect physicians' instructions & $295(41.5)$ & $27(15.5)$ & $322(36.4)$ & 40.74 & 0.001 \\
\hline Workplace is safe & $338(47.5)$ & $94(54.0)$ & $432(48.8)$ & 2.35 & 0.125 \\
\hline Administrative procedures negatively affect work & $620(87.2)$ & $158(90.8)$ & $778(87.9)$ & 1.71 & 0.191 \\
\hline Job autonomy ${ }^{\mathrm{a}}$ & $272(38.3)$ & $106(60.9)$ & $378(42.7)$ & 29.34 & 0.001 \\
\hline
\end{tabular}

${ }^{a}$ The ability to take decisions when necessary. 


\begin{tabular}{|c|c|c|c|c|c|}
\hline Factors & $\begin{array}{c}\text { Students }(n=711) \\
\text { No. }(\%)\end{array}$ & $\begin{array}{c}\text { Residents }(n=174) \\
\text { No. }(\%)\end{array}$ & $\begin{array}{c}\text { Total }(n=885) \\
\text { No. }(\%)\end{array}$ & $\chi^{2}$ & $\mathbf{P}$ \\
\hline University education makes you a good doctor & $220(30.9)$ & $87(50.0)$ & $307(34.7)$ & 22.41 & 0.001 \\
\hline $\begin{array}{l}\text { Length of training is enough to make you a } \\
\text { successful doctor }\end{array}$ & $164(23.1)$ & $56(32.2)$ & $220(24.9)$ & 6.22 & 0.013 \\
\hline $\begin{array}{l}\text { All opportunities and facilities for scientific } \\
\text { research are available }\end{array}$ & $123(17.3)$ & $43(24.7)$ & $166(18.8)$ & 5.04 & 0.025 \\
\hline $\begin{array}{l}\text { Want to emigrate for better research } \\
\text { opportunities }\end{array}$ & $606(85.2)$ & $166(95.4)$ & $772(87.2)$ & 12.98 & 0.001 \\
\hline $\begin{array}{l}\text { Paid vacation during postgraduate studies is } \\
\text { enough }\end{array}$ & $235(33.1)$ & $66(37.9)$ & $301(34.0)$ & 1.48 & 0.223 \\
\hline $\begin{array}{l}\text { Paid vacation during emergency incidents is } \\
\text { enough }\end{array}$ & $65(9.1)$ & $13(7.5)$ & $78(8.8)$ & 0.49 & 0.486 \\
\hline Physicians' living arrangements in hospital & & & & 49.10 & 0.001 \\
\hline Excellent & $13(1.8)$ & $3(1.7)$ & $16(1.8)$ & & \\
\hline Good & $155(21.8)$ & $52(29.9)$ & $207(23.4)$ & & \\
\hline Bad & $353(49.6)$ & $115(66.1)$ & $468(52.9)$ & & \\
\hline Don't know & $190(26.8)$ & $4(2.3)$ & $194(21.9)$ & & \\
\hline $\begin{array}{l}\text { Insurance against professional errors is } \\
\text { appropriate and enough }\end{array}$ & $311(43.7)$ & $150(86.2)$ & $461(52.1)$ & 101.01 & 0.001 \\
\hline Satisfied with infection compensation & $7(1.0)$ & $1(0.6)$ & $8(0.9)$ & $\mathrm{FE}$ & 1.000 \\
\hline $\begin{array}{l}\text { Appropriate and adequate surgical and } \\
\text { medical supplies are available to help one do } \\
\text { one's job well }\end{array}$ & $130(18.3)$ & $41(23.6)$ & $171(19.3)$ & 2.50 & 0.114 \\
\hline Medical staff-to-patient ratio is appropriate & $99(13.9)$ & $29(16.7)$ & $128(14.5)$ & 0.85 & 0.357 \\
\hline Job promotion procedures & & & & 1.39 & 0.498 \\
\hline Very easy & $14(2.0)$ & $2(1.1)$ & $16(1.8)$ & & \\
\hline Easy & $55(7.7)$ & $10(5.7)$ & $65(7.3)$ & & \\
\hline Difficult & $642(90.3)$ & $162(93.2)$ & $804(90.9)$ & & \\
\hline
\end{tabular}

FE= Fisher exact test.

Among our participants, $89.4 \%$ said they wanted to emigrate. Lower percentages of emigration intention among medical professionals have been reported in other countries: 61.0\% for Iraq (15), 60.4\% for Pakistan (16), 53.0\% for Ethiopia (17), 44.6\% for Uganda (18), 40.0\% for Nepal (19), $59.0 \%$ for India (20) and $55.0 \%$ for Portugal (21). These differences indicate that prevalence of and motivations for physician migration vary by country across the world.

Our study detected and highlighted different motivating factors pushing physicians to consider emigration. The factors with which the participants were most dissatisfied and motivated the desire to emigrate were financial, such as inadequate salary for the working hours and occupational hazards. In addition, physicians had to work extra time in private hospitals because of the inadequate salary, which resulted in high workloads that reduced the time they had available for their families, friends and leisure.

Our findings are in line with other studies of physicians and medical students in Uganda (18), Croatia (22), Sri Lanka (23) and Romania (3). These studies reported that low salaries were the main reason for physician emigration. This finding indicates that better incentives and salaries could help in solve this problem of emigration. This should be a warning to governmental health system in LMICs that financial disincentives may force medical professionals out of their countries.

As regards sociopolitical factors, most physicians wanted to emigrate to improve their social position as they did not feel adequately appreciated by their country and society. In addition, our participants felt that a biased focus on physicians' medical errors by the media was unfair and frustrating.

Our study also showed the effect of the workplace environment in motivating a desire to emigrate. Our participants suffered from bad behaviour of their patients and their relatives: they were exposed to verbal abuse and physical assault and felt unsafe in their workplace. These findings concur with other studies in Egypt (24), Ireland (25), Ethiopia (17) and Nepal (19) that showed unsafe working conditions as a major reason for physician emigration. Safety and security in hospitals are basic needs for any successful health system in any country.

As regards professional reasons for physician emigration in Egypt, inadequate length of training to be a skilled doctor, lack of surgical and medical supplies, and few research opportunities and facilities in Egypt were reasons for wanting to emigrate. Better training and 
research opportunities were important reasons in other studies among physicians in Pakistan (16), Lebanon (26), India (20) and Mongolia (27).

An encouraging result of this study was that responders said that their desire to emigrate could change if the health sector in Egypt improved. Another study of Egyptian medical students found that $81.8 \%$ of the participants planned to return to Egypt after training to serve their home country (24). Another promising point in our results is that residents generally had less of a negative attitude to workplace and professional factors than students. The perceptions of students is more based on observation and experiences of others, while those of residents reflect their own experience after starting work as a doctor.

Our study reflects the experience of medical students and junior physicians in Lower Egypt, which could be different from students and residents in Upper Egypt and the main cities of Cairo and Alexandria. Our large sample size can ensure representativeness of the results to the target population.

To conclude, Egyptian medical students and young physicians have a strong desire to emigrate abroad to seek better working conditions, lifestyle, financial incentives and research opportunities. A retention policy needs to be developed with strategic actions to prevent Egyptian physicians from emigrating to other countries.

\section{Acknowledgement}

We thank the students of the fourth academic year who shared in data collection.

Funding: None

Competing interests: None declared.

\section{Fuite des cerveaux : pourquoi les étudiants en médecine et les jeunes médecins veulent quitter l'Égypte \\ Résumé}

Contexte : L'Égypte fait face à une pénurie de médecins malgré les milliers d'étudiants en médecine qui obtiennent leur diplôme chaque année.

Objectifs : La présente étude visait à explorer les raisons pour lesquelles les étudiants en médecine et les jeunes médecins égyptiens souhaitent émigrer.

Méthodes : Cette étude transversale, menée de février à avril 2019, incluait 711 étudiants de cinquième et sixième année et 174 médecins résidents de deux facultés de médecine en Égypte, à savoir celle de Tanta et de Kafr el-Cheikh. Un questionnaire a été utilisé pour recueillir des données sur les facteurs sociodémographiques, la volonté d'émigrer et les motifs sous-jacents.

Résultats: La plupart des participants (89,4\%) souhaitaient émigrer, et pensaient que leur salaire n'était pas compatible avec leur temps de travail ou les risques du métier. Près de la moitié des participants (52,8\%) travaillaient à temps partiel dans des hôpitaux privés. Seuls 4,9\% des participants se sentaient valorisés par le pays. La plupart des participants (75,9\%) n'étaient pas satisfaits de leurs relations avec les patients et $40,2 \%$ n'étaient pas satisfaits de leurs relations avec leurs collègues. Des agressions verbales ont été rapportées par 55,5\% des participants et des agressions physiques par 35,4\%. La plupart des participants qui souhaitaient émigrer $(85,1 \%)$ ont déclaré qu'ils changeraient d'avis si des améliorations étaient apportées dans le secteur de la santé. Les médecins résidents avaient généralement une attitude moins négative que les étudiants à l'égard de l'environnement de travail et des facteurs professionnels.

Conclusion: Les médecins émigrent en quête de meilleures conditions de travail et d'un meilleur salaire. Une politique de fidélisation doit être mise en place pour empêcher les médecins égyptiens d'émigrer.

$$
\begin{aligned}
& \text { هجرة الأدمغة: لماذا يريد طلاب الطب وشباب الأطباء مغادرة مصر؟ } \\
& \text { إبر اهيم كباش، رانيا السلامي، هناء زايد، إبراهيم الخياط، أحمد عمر، سناء عبده } \\
& \text { الخلاصة } \\
& \text { الخلفية: تعاني مصر من نقصٍ في عدد الأطباء، برغم تخرُج الآلاف من طلاب الطب سنويَّا. } \\
& \text { الأهداف: هدفت هذه الدراسة إلى استكشاف أسباب رغبة طلاب الطب وشباب الأطباء المصريين في الهجرة. }
\end{aligned}
$$




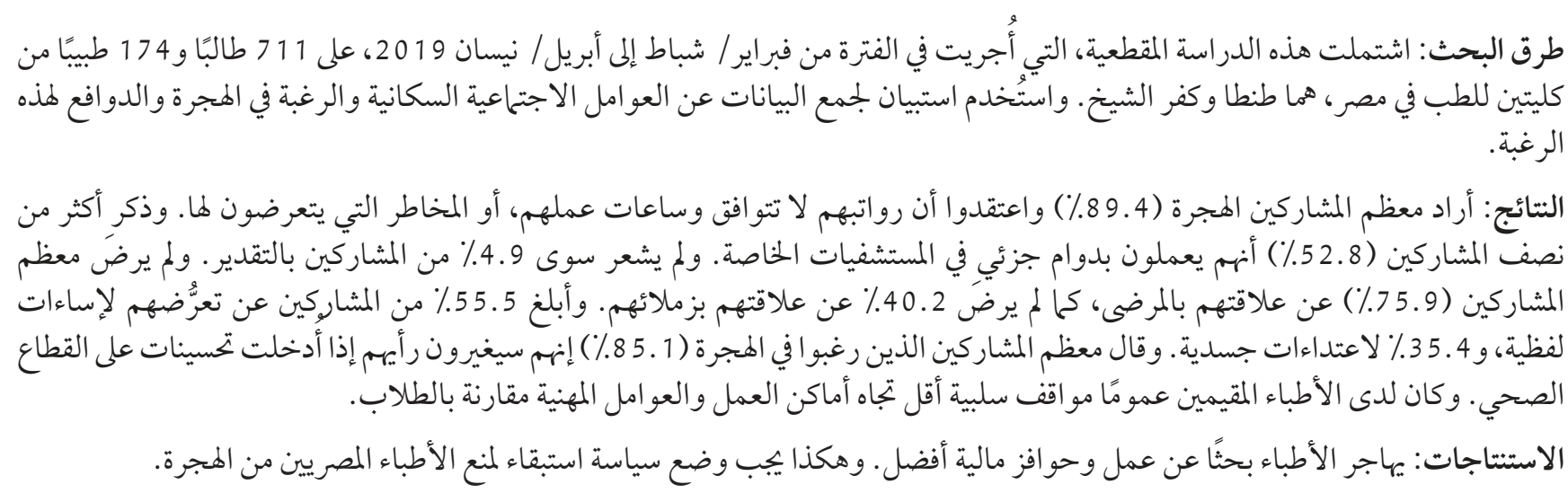

\section{References}

1. Global Health Workforce Alliance and World Health Organization. A universal truth: no health without a workforce. Geneva: World Health Organization; 2013. (http://www.who.int/workforcealliance/knowledge/resources/GHWA_AUniversalTruthRee port.pdf, accessed 13 October 2020).

2. OECD data. Doctors [Internet]. Paris: Organisation for Economic Co-operation and Development; 2016 (https://data.oecd.org/ healthres/doctors.htm, accessed 13 October 2020.

3. Suciu SM, Popescu CA, Ciumageanu MD, Buzoianu AD. Physician migration at its roots: a study on the emigration preferences and plans among medical students in Romania. Hum Resour Health. 2017;15(1):6. https://doi.org/10.1186/s12960-017-0181-8

4. Liu JX, Goryakin Y, Maeda A, Bruckner T, Scheffler R. Global health workforce labor market projections for 2030. Hum Resour Health. 2017;15(1):11. https://doi.org/10.1186/s12960-017-0187-2

5. Crisp N, Chen L. Global supply of health professionals. N Engl J Med. 2014;370(10):950-7. https://doi.org/10.1056/NEJMra1111610

6. Moszynski P. One billion people are affected by global shortage of healthcare workers. BMJ. 2011;342:d696. https://doi. org/10.1136/bmj.d696

7. Aluttis C, Bishaw T, Frank MW. The workforce for health in a globalized context: global shortages and international migration. Glob Health Action. 2014;7:23611. https://doi.org/10.3402/gha.v7.2361

8. The World Health Report, 2006. Working together for health. Geneva: World Health Organization; 2006 (https://apps.who.int/ iris/handle/10665/43432, accessed 13, August 2021).

9. Duvivier RJ, Burch VC, Boulet JR. A comparison of physician emigration from Africa to the United States of America between 2005 and 2015. Hum Resour Health. 2017;15(1):41. https://doi.org/10.1186/s12960-017-0217-0

10. Asongu S. The impact of health worker migration on development dynamics: evidence of wealth effects from Africa. Yaoundé, African Governance and Development Institute; 2012 (http://www.afridev.org/RePEc/agd/agd-wpaper/The-imtl pact-of-health-worker-migration-on-development-dynamics.-Evidence-of wealth-effects-from-Africa.pdf, accessed 6 August 2021).

11. Bhargava A, Docquier F, Moullan Y. Modeling the effects of physician emigration on human development. Econ Hum Biol. 2011;9(2):172-83. https://doi.org/10.1016/j.ehb.2010.12.004

12. Okeke EN. Do higher salaries lower physician migration? Health Policy Plann. 2014;29(5):603-14 https://doi.org/10.1093/heapol/ czto46

13. Global Health Observatory data repository [Internet]. Geneva: World Health Organization (http://apps.who.int/gho/data/node. main.A1444, accessed 6 August 2021).

14. Abdelaziz A, Kassab SE, Abdelnasser A, Hosny S. Medical education in Egypt: historical background, current status, and challenges. Health Prof Educ. 2018;4(4):236-44. https://doi.org/10.1016/j.hpe.2017.12.007

15. Burnham G, Malik S, Al-Shibli ASD, Mahjoub AR, Baqer AQ, Baqer ZQ et al. Understanding the impact of conflict on health services in Iraq: information from 401 Iraqi refugee doctors in Jordan. Int J Health Plann Manage. 2012;27(1):e51-e64. https://doi. org/10.1002/hpm.1091

16. Sheikh A, Naqvi SH, Sheikh K, Naqvi SH, Bandukda MY. Physician migration at its roots: a study on the factors contributing towards a career choice abroad among students at a medical school in Pakistan. Global Health. 2012;8:43. https://doi. org/10.1186/1744-8603-8-43

17. Deressa W, Azazh A. Attitudes of undergraduate medical students of Addis Ababa University towards medical practice and migration, Ethiopia. BMC Med. Educ. 2012;12(68). https://doi.org/10.1186/1472-6920-12-68

18. Kizito S, Mukunya D, Nakitende J, Nambasa S, Nampogo A, Kalyesubula R, et al. Career intentions of final year medical students in Uganda after graduating: the burden of brain drain. BMC Med. Educ. 2015;15:122. https://doi.org/10.1186/s12909-015-0396-0

19. Lakhey M, Lakhey S, Niraula SR. Comparative attitude and plans of the medical students and young Nepalese doctors. Kathmandu Univ Med J (KUMJ). 2009;7(26):177-82. https://doi.org/10.1097/00001888-200602000-00015 
20. Rao NR, Rao UK and Cooper RA. Indian medical students' views on immigration for training and practice. Acad Med. 2006;81(2):185-8. https://doi.org/10.1097/00001888-200602000-00015

21. Ramos P, Alves H. Migration intentions among Portuguese junior doctors: results from a survey. Health Policy. 2017; 121(12):1208-14. https://doi.org/10.1016/j.healthpol.2017.09.016

22. Bojanic A, Bojanic K and Likic R. Brain drain: final year medical students' intentions of training abroad. Postgrad Med J. 2015;91(1076):315-21. https://doi.org/10.1136/postgradmedj-2014-132908

23. de Silva NL, Samarasekara K, Rodrigo C, Samarakoon L, Fernando SD, Rajapakse S. Why do doctors emigrate from Sri Lanka? A survey of medical undergraduates and new graduates. BMC Res Notes. 2014;7:918. https://doi.org/10.1186/1756-0500-7-918

24. Fouad YA, Fahmy YM, Abdel Hady SM, Elsabagh AE. Egyptian future physicians are packing to leave but may be willing to return. Int Health. 2015;7(3):190-4. https://doi.org/10.1093/inthealth/ihu072

25. Gouda P, Kitt K, Evans DS, Goggin D, McGrath D, Last J, Hennessy M, et al. Ireland's medical brain drain: migration intentions of Irish medical students. Hum. Resour Health. 2015;13:11. https://doi.org/10.1186/s12960-015-0003-9

26. Akl EA, Maroun N, Major S, Afif C, Abdo A, Choucair J, et al., Post-graduation migration intentions of students of Lebanese medical schools: a survey study. BMC Public Health. 2008;8:191. https://doi.org/10.1186/1471-2458-8-191

27. Wells KM, Shalabi H, Sergelen O, Wiessner P, Zhang C, deVries C, et al. Patient and Physician perceptions of changes in surgical care in Mongolia 9 years after roll-out of a national training program for laparoscopy. World J Surg. 2016;40(8):1859-64. https:// doi.org/10.1007/s00268-016-3498-x 